\title{
Nursing work in the surgical ward and psychosocial risks related to management modes
}

\author{
Trabalho da enfermagem no centro cirúrgico e os riscos \\ psicossociais relacionados aos modos de gestão \\ Trabajo de enfermería en quirófano y los riesgos psicosociales \\ relacionados con los modos de gestión
}

\section{Bruna Pires Madrida Kamille Kotekewis ${ }^{\mathrm{b}}$ Cecília Helena Glanzner ${ }^{c}$}

\section{How to cite this article:} Madrid BP, Kotekewis K, Glanzner CH. Nursing work in the surgical ward and psychosocial risks related to management modes. Rev Gaúcha Enferm. 2020:41:e20190447. doi: https://doi. org/10.1590/1983-1447.2020.20190447 a Pesquisador autônomo. Porto Alegre. Rio Grande do Sul, Brasil.

b Hospital de Clínicas de Porto Alegre (HCPA). Porto Alegre. Rio Grande do Sul, Brasil.

Universidade Federal do Rio Grande do Sul (UFRGS), Escola de Enfermagem, Departamento de Enfermagem Médico-Cirúrgica. Porto Alegre. Rio Grande do Sul, Brasil.

\section{ABSTRACT}

Aim: To evaluate the management modes in the workplace of the nursing staff of the surgical ward of a university hospital.

Methods: Cross-sectional, descriptive, quantitative and analytical study performed in the Surgical Ward of a university hospital in southern Brazil. Sample consisted of 160 nursing workers who answered the Management Styles Assessment Scale. Comparisons were made using Student's t-test and One-Way analysis of variance (ANOVA), Pearson's chi-square test, multiple comparisons test and multiple linear regression analyzes.

Results: The Collectivist style was classified as "Predominant" by 46.2\% (72) of the workers. The Normative and Directive styles were rated as "Moderate Presence" by 53.2\% (84) and 50.3\% (77), respectively. The Individualist style was rated as "Unremarkable" by $60.6 \%$ (94) of the sample.

Conclusions: The presence of collectivist management meets the characteristics of nursing work, which is patient care, planned and performed jointly and in line with the multiprofessional team in the pursuit of comprehensive care.

Keywords: Operating room nursing. Personnel management. Occupational health.

\section{RESUMO}

Objetivo: Avaliar os modos de gestão no trabalho da equipe de enfermagem do centro cirúrgico de um hospital universitário.

Métodos: Estudo transversal, descritivo, quantitativo e analítico realizado no Centro Cirúrgico de um hospital universitário do Sul do Brasil. A amostra foi composta por 160 trabalhadores de enfermagem que responderam a Escala de Estilos de Gestão. Comparações foram realizadas pelo teste $t$ de Student e pela análise de variância One-Way (ANOVA), teste qui-quadrado de Pearson, teste de comparações múltiplas e análises de regressão linear múltipla.

Resultados: 0 estilo Coletivista foi classificado como "Predominante" por 46,2\% (72) dos trabalhadores. Os estilos Normativo e Realizador foram avaliados como "Presença Moderada" por 53,2\% (84) e 50,3\% (77), respectivamente. 0 estilo Individualista foi avaliado como"Pouco Característico" por 60,6\% (94) da amostra.

Conclusões: A presença da gestão coletivista vai ao encontro das características do trabalho em enfermagem que é o cuidado ao paciente, planejado e realizado em conjunto e, em consonância com a equipe multiprofissional na busca da assistência integral.

Palavras-chave: Enfermagem de centro cirúrgico. Administração de recursos humanos. Saúde do trabalhador.

\section{RESUMEN}

Objetivo: Evaluar los modos de gestión en el trabajo del personal de enfermería del quirófano de un hospital universitario.

Métodos: Estudio transversal, descriptivo, cuantitativo y analítico realizado en el Centro Quirúrgico de un hospital universitario en el sur de Brasil. La muestra consistió en 160 trabajadores de enfermería que respondieron a la Escala de estilos de gestión. Las comparaciones se realizaron mediante la prueba t de Student y el análisis de varianza de una vía (ANOVA), la prueba de chi-cuadrado de Pearson, la prueba de comparaciones múltiples y los análisis de regresión lineal múltiple.

Resultados: El estilo colectivista fue clasificado como"predominante" por el 46,2\% (72) de los trabajadores. Los estilos Normativo y Director fueron calificados como "Presencia moderada" por 53.2\% (84) y 50.3\% (77), respectivamente. El estilo individualista fue calificado como"No destacable" por el 60,6\% (94) de la muestra.

Conclusiones: La presencia del manejo colectivista cumple con las características del trabajo de enfermería, que es la atención al paciente, planificada y realizada conjuntamente y en línea con el equipo multiprofesional en la búsqueda de una atención integral. Palabras clave: Enfermería de quirófano. Administración de personal. Salud laboral. 


\section{口INTRODUCTION}

Work is currently perceived as a fundamental and determining element for the health of the individuals, being associated with their lifestyle. Workers are exposed to several risks, with emphasis to psychosocial risks related to the work environment ${ }^{(1)}$. Psychosocial risks are adverse effects related to the organization of work that affect workers' health and have a negative impact on work quality. They can be associated to management styles, pathogenic suffering and physical, psychological and social damage ${ }^{(2)}$.

Nursing is directly responsible for the development of actions aimed at promoting health, preventing illness and recovering the population's health. These activities are characterized by high complexity demands, which may pose psychosocial risks to workers, regardless of the site of professional activity ${ }^{(2)}$. Therefore, management models are being developed to meet the demands of health institutions in the implementation of management practices that promote effective improvements in socio-professional relationships, in the organization of work, in achieving good results and in the assurance of high quality of care, and the contribution provided by these practices is important for the quality of life in the workplace ${ }^{(3)}$.

The complexity of care production is more evident in the hospital environment, and the managerial work of nurses has been crucial for the coordination between the various health team professionals, who, in addition to organizing and disseminating strategies for improving care, seek to implement actions aimed at meeting customer needs ${ }^{(4)}$.

Therefore, the "management" function in the hospital environment involves greater complexity, as it aims at satisfying internal and external customers, constantly seeking to comply with the quality standards in health care ${ }^{(5)}$. In this regard, the Surgical Ward (SW is considered a high risk scenario, as its work processes involve dynamic, unpredictable, complex, interdisciplinary and urgent practices ${ }^{(6)}$.

Nurses provide care, plan assistance, lead, coordinate the production of care, assess nursing actions, manage material and human resources and trains the nursing team. It is known that manager nurses who work in hospitals develop multiple tasks with high-level requirements, and such tasks can interfere with the quality of care, depending on how the work is organized and the knowledge and leadership practices adopted ${ }^{(7)}$.

In the surgical ward scenario, the work of all members of the nursing team is constantly pervaded by management activities, i.e. management of people, patient flow, equipment, instruments and materials, and this process may pose a psychosocial risk to the workers. In this regard, the management styles scale (EEG) allows the assessment of different modes of management in the workplace, based on the psychodynamics of work ${ }^{(8)}$.

This tool assesses four management styles, namely: collectivist, normative, individualist and directive. In the collectivist management style, the organization is perceived as a perfect group, reflecting pride, trust and organizational self-esteem, in which the members show loyalty, dependency and attachment to the corporation, valuing idealization, cohesion and unity. The predominance of the normative management style characterizes a management where regulations and rules must be strictly followed in the workplace. It values planning and has little concern with the personal problems of its members. Thus, the emotional ties between people and the organization and between its members are not strong ${ }^{(8)}$.

The predominance of the individualist management style is characterized by the concern with the satisfaction of needs of recognition and esteem and the centrality of its members in the organizational dynamics. In the directive management style, the ways of thinking, feeling and acting are focused on productivity, competitiveness and professional fulfillment. By prioritizing the search for promotion, this management style reinforces the need for the existence of hierarchical levels and values the recognition obtained with the prestige achieved through a great professional reputation ${ }^{(8)}$.

Nursing care management is a nurse's assignment that directly impacts the promotion of high quality care and best working conditions for nursing workers ${ }^{(7)}$. However, several challenges faced by care management can be solved through strategies and actions tailored to the needs of each workplace, which are idealized and performed by all the professionals involved, particularly nursing technicians and assistants, as they are the largest part of the workforce in the Brazilian health system ${ }^{(9)}$.

Studies indicate that psychosocial risks at work have been growing in recent years and contributing to the worsening of workers' health. In addition to interfering with patient care, costs associated with psychosocial risks at work have increased ${ }^{(2)}$.

In view of the above, the following questions are asked: are there different ways of managing the work of the nursing team in the surgical ward, in the post-anesthesia care unit (recovery room), in the ambulatory surgery center and in the materials and sterilization center of a university hospital? What are the existing management modes? Is there a difference in the predominance of management modes between the units of the surgical ward and according to work shifts? In order to answer these questions, the present study aims to evaluate the management modes in the workplace of the nursing team at the surgical ward of a university hospital. 


\section{METHODS}

Cross-sectional, descriptive, quantitative and analytical study performed at the Surgical Ward (UBC) of a university hospital in southern Brazil. The Surgical Ward includes the following areas: Surgical Ward Unit (UBC), Ambulatory Surgery Center (CCA), Post-Anesthesia Care Unit (URPA) and Material and Sterilization Center (CME) ${ }^{(10)}$.

The hospital where the study was conducted admits patients from the Unified Health System (SUS), with health insurance and private patients. The UBC is intended for patients recovering from low, medium and high complexity patients in the perioperative care in conventional, laparoscopic and robotic surgeries. The URPA receives adult and pediatric patients from the UBC for immediate recovery from surgical procedures. Unlike the other units, the Ambulatory Surgery Center is separate from the UBC and receives patients recovering from low and medium complexity procedures in conventional and laparoscopic surgeries. Endoscopic procedures are also performed in the ambulatory surgery center, and adult and pediatric patients recover from surgery in the post-anesthesia recovery room and sedation/procedure room, both located in the ambulatory center. The CME performs all the disinfection and sterilization processes of the hospital's reprocessed products ${ }^{(11)}$.

The study was conducted from November 2017 to January 2018. The population consisted of 350 workers from the nursing team of the Nursing Service in a Surgical Ward. The sample consisted of 160 participants and was determined by statistical calculation, so that it was possible to detect a difference in effect size greater than or equal to 0.25 ( 0.2 on scales 1 and 2 and, 0.25 on scales 3 and 4 ) of the surgical areas, considering a power of $80 \%$ and a significance level of 0.05 . The workers were randomly drawn until the desired sample size was reached.

The sample included nurses, nursing technicians and nursing assistants who had been working in the surgical units for six months or longer, in the morning, afternoon and night shifts (there are three night teams called N1, N2 and N3 in the hospital where the study was conducted), teams that work in non-traditional shifts (from $5 \mathrm{pm}$ to $11 \mathrm{pm}$ in the 4 units and in URPA, and also those workers who perform their duties from 10 am to $4 \mathrm{pm}$ ) and in the weekends (nurses). Workers who were away, on vacation or on leave for any reason during the data collection period were excluded.

Os dados foram coletados por uma equipe de pesquisa previamente capacitada que aplicou a Escala de Estilos de Gestão (EEG). Esta é uma das quatro escalas do Protocolo de Avaliação dos Riscos Psicossociais no Trabalho (PROART) de Facas (2013), e seus itens se referem às formas de sentir, pensar e agir compartilhadas na organização, que são consideradas partes constituintes do estilo de gestão adotado ${ }^{(12)}$. Data was collected by a previously trained research team that administered the Management Style Scale (EEG). This is one of the four scales of the Protocol for the Assessment of Psychosocial Risks in the Workplace (PROART), of Facas (2013), and its items refer to the ways of feeling, thinking and acting shared in the organization, which are considered to be part of the management style adopted ${ }^{(12)}$.

The EEG is composed of 23 items and divided into four factors: individualist, normative, collectivist and directive management style. The assessment is based on a Likert scale of frequency, consisting of five points: $1=$ Never; 2 $=$ Rarely $; 3=$ Sometimes; 4 = Often; 5 = Always. According to the parameters established by the tool, the standard deviation from the midpoint was considered, and for the evaluation of the mean and frequency of the factors, the mean value is 3; values close to the midpoint of the scale indicate a moderate presence of a certain style, whereas for values above 3.5 the pattern is predominant, and for values below 2.5 , the pattern is considered to be unremarkable ${ }^{(12)}$.

The data were organized and entered twice in an Excel spreadsheet and later analyzed using the Statistical Package for the Social Sciences (SPSS) software, version 22.0. Descriptive analysis was performed using simple and relative frequencies for categorical variables, and central tendency (mean or median) and dispersion measures (standard deviation and quartiles) for continuous variables.

Student's t test, One-Way analysis of variance (ANOVA), Pearson's chi-square test, least significance difference test for multiple comparisons were used to compare EEG management styles between sociodemographic and labor variables, when required. The characteristics that obtained values of $P$ $<0.20$ were included in multiple linear regression analyzes (one for each management style) and to identify the variables that influenced the management styles. P values $<0.05$ were considered significant in this study ${ }^{(13)}$.

The present study complied with the ethical criteria provided for in Resolution No. 466/2012 (14) and was approved by the Research Ethics Committee of the institution - CAAE: 65993517.9.0000.5327. The selected workers were invited to participate in the study on a voluntary basis and those who agreed to participate signed the Free and Informed Consent Term (TCLE), which states the researcher's commitment to preserve the collected data and identity of the participants. The form is signed by the researcher in two copies, and one is given to the respondent. 


\section{RESULTS}

The participants of the study were 160 nursing workers, of which $84.5 \%$ (131) were women and $57.3 \%$ (86) were 45 years old or over. Regarding their professional occupation, 63.1\% (101) were nursing technicians, 16.9\% (27) nursing assistants and 20\% (32) were nurses. As for the workplace, $30 \%$ (48) worked in the Surgical Ward (BC), 30\% (48) in the Ambulatory Surgery Center (CCA), 22.5\% (36) at the Material and Sterilization Center (CME), 17.5\% (28) at the Post-Anesthesia Care Unit (URPA). Regarding the distribution according to shifts, $28.1 \%$ (45) worked in the morning shift, 30\% (48) in the afternoon shift, $34.4 \%$ (55) in the night shift, $7.5 \%$ (12) only at weekends or in a non-traditional shift (6 hours a day, at alternative, predetermined periods, according to the demand of each sector).

Regarding the length of time working in the institution, 34 (52) said they have been working there over a period ranging from 10 years and 1 month to 20 years. Regarding the periodic medical examination, $96.1 \%$ (149) reported having performed this examination in the last year and $60.9 \%$ (95) said they were not away from work in the same period. It was a yes-no question that did not consider the reason for being away from work. Regarding lifestyle, 94.2\% (146) said they were not smokers; $62.3 \%$ (94) did not do regular physical activity; $70.3 \%$ (109) reported sleeping well and have been working in the health institution for a period ranging from 10 years and 1 month to 20 years, and 27.5\% (42) for more than 20 years.

Table 1 shows the results of the means and standard deviation of each EEG item answered by the workers of the surgical units evaluated, regarding management styles, which were defined as the factors of the scale.

Considering the scale parameters and the results presented in table 1, the "Individualist"factor was unremarkable among the workers evaluated, as four of the five items had a mean below 2.5. As for the "Normative" factor, the means had a longer interval, with five items classified as moderate presence and one as predominant. Moreover, item seven "hierarchy is valued in this organization" had the highest mean of all factors of the scale. In the "collectivist" factor, the means $s$ also showed wide variation, and three of the six items were characterized as predominant. Regarding the "Directive" factor, five items were classified as moderate presence and one as predominant.

Table 2 shows the presence of each management style in the participants of the study, being characterized as "unremarkable", "moderate presence" or "predominant".

The Individualist management style was rated as "unremarkable" by $60.6 \%$ (94) of the sample. As for the Normative style, 53.2\% (84) said they had a "moderate presence" of this style. As for the collectivist style, $46.2 \%$ (72) of the workers

Table 1 - Mean and standard deviation of items of the Management Style Scale answered by workers in the units of the surgical ward, Porto Alegre/RS, 2017-2018

\begin{tabular}{|c|c|c|c|c|}
\hline Style & No & Item & Mean & SD \\
\hline \multirow{5}{*}{ INDIVIDUALIST } & 01 & In my workplace, overpraising the bosses is encouraged & 2.32 & 1.249 \\
\hline & 02 & $\begin{array}{l}\text { In this organization, the managers consider themselves the center of } \\
\text { the world }\end{array}$ & 2.34 & 1.219 \\
\hline & 03 & The managers of this organization do anything to draw attention & 2.54 & 1.184 \\
\hline & 04 & Here managers prefer to work alone & 2.28 & 1.274 \\
\hline & 05 & The managers consider themselves irreplaceable & 2.18 & 1.221 \\
\hline \multirow{6}{*}{ NORMATIVE } & 06 & This organization attaches great importance to the rules & 3.78 & 0.999 \\
\hline & 07 & Hierarchy is valued in this organization & 4.11 & 0.894 \\
\hline & 08 & $\begin{array}{l}\text { The emotional bonds between the people who work in this organization } \\
\text { are weak }\end{array}$ & 2.99 & 1.012 \\
\hline & 09 & Work is tightly controlled & 3.43 & 0.962 \\
\hline & 10 & Changes cause disorganization in the workplace & 3.02 & 0.942 \\
\hline & 11 & There is a strict planning of actions & 3.31 & 1.040 \\
\hline
\end{tabular}


Table 1 - Cont.

\begin{tabular}{|c|c|c|c|c|}
\hline Style & No & Item & Mean & SD \\
\hline \multirow{6}{*}{ COLLECTIVIST } & 12 & Managers do not tolerate individualism & 2.64 & 0.961 \\
\hline & 13 & $\begin{array}{l}\text { People are committed to the organization even when they are not } \\
\text { adequately valued }\end{array}$ & 3.3 & 0.935 \\
\hline & 14 & Everyone has credit for the achievements in the company & 3.51 & 1.206 \\
\hline & 15 & Collective work is valued by managers & 3.57 & 0.949 \\
\hline & 16 & $\begin{array}{l}\text { For this organization, the result of the work is seen as an achievement } \\
\text { of the group }\end{array}$ & 3.68 & 0.927 \\
\hline & 17 & In this organization decisions are made in group & 2.89 & 1.083 \\
\hline \multirow{6}{*}{ DIRECTIVE } & 18 & We are encouraged by managers to seek new challenges & 3.35 & 0.990 \\
\hline & 19 & Managers favor the interactive work of professionals from different areas & 3.09 & 0.926 \\
\hline & 20 & The competence of workers is valued by the management & 3.30 & 0.998 \\
\hline & 21 & There are similar opportunities for growth for all people & 2.84 & 1.082 \\
\hline & 22 & Managers care about the welfare of workers & 3.16 & 0.978 \\
\hline & 23 & Innovation is valued in this organization & 3.52 & 0.949 \\
\hline
\end{tabular}

Source: Research data, 2017-2018.

Table 2 - Categorization of participants according to management styles in the units of the surgical ward. Porto Alegre/RS, 2017-2018

\begin{tabular}{ccccc} 
Style & Unremarkable (\%) & $\begin{array}{c}\text { Moderate presence } \\
\mathbf{N}(\%)\end{array}$ & $\begin{array}{c}\text { Predominant } \\
\mathbf{N}(\%)\end{array}$ & $\begin{array}{c}\text { Total } \\
\mathbf{N}(\%)\end{array}$ \\
\hline Individualist & $94(60.6 \%)$ & $37(23.9 \%)$ & $24(15.5 \%)$ & $155^{*}(100 \%)$ \\
Normative & $4(2.6 \%)$ & $84(53.2 \%)$ & $68(43.6 \%)$ & $156^{*}(100 \%)$ \\
Collectivist & $17(10.9 \%)$ & $67(42.9 \%)$ & $72(46.2 \%)$ & $156^{*}(100 \%)$ \\
Directive & $28(18.3 \%)$ & $77(50.3 \%)$ & $48(31.4 \%)$ & $153^{*}(100 \%)$ \\
\hline
\end{tabular}

Source: Research data, 2017-2018

* The instruments that lacked answers in any of the items (missing) were disregarded.

considered it "predominant", and regarding the Directive style, 50.3\% (77) presented a "moderate presence" of this management style.

Table 3 shows the management styles in each unit of the surgical ward, according to the participants' responses.

In the Individualist style, the UBC (66\%) was the least remarkable unit for this management style. In the Normative style, URPA (66.7\%) was the only unit in which this management style was predominant, whereas the other units had a moderate presence of the referred style. As for the collectivist style, the CME (73.5\%) was the unit with the greatest moderate presence of this management style, followed by CCA (59.1\%) and UBC (55.3\%). As for URPA, it obtained the same score in the predominant (42.9\%) and moderate presence (42.9\%) classifications in the Collectivist style. As for the Directive style, the unit with the greatest moderate presence of this style was URPA (57.7\%), followed by UBC (56.5\%) and CME (54.3\%); the CCA had a higher score in the predominant (37\%) and moderate presence (37\%) classifications in the Directive style. 
Table 3 - Management styles in the surgical ward units investigated. Porto Alegre/RS, 2017-2018

\begin{tabular}{|c|c|c|c|c|}
\hline Sector & UBC & CCA & CME & URPA \\
\hline \multicolumn{5}{|c|}{ Individualist Style } \\
\hline Predominant & $6(12.8 \%)$ & $6(12.8 \%)$ & $8(24.2 \%)$ & $4(14.3 \%)$ \\
\hline Moderate presence & $10(21.3 \%)$ & $11(23.4 \%)$ & $7(21.2 \%)$ & $9(31.1 \%)$ \\
\hline Unremarkable & $31(66 \%)$ & $30(63.8 \%)$ & $18(54.5 \%)$ & 15 (53.6\%) \\
\hline Total & $47(100 \%)$ & $47(100 \%)$ & $33(100 \%)$ & $28(100 \%)$ \\
\hline \multicolumn{5}{|c|}{ Normative Style } \\
\hline Predominant & $20(43.5 \%)$ & $16(33.3 \%)$ & $14(40 \%)$ & $18(66.7 \%)$ \\
\hline Moderate presence & $25(54.3 \%)$ & $29(60.4 \%)$ & $21(60 \%)$ & $9(33.3 \%)$ \\
\hline Unremarkable & $1(2.2 \%)$ & $3(6.3 \%)$ & 0 & 0 \\
\hline Total & $46(100 \%)$ & $48(100 \%)$ & $35(100 \%)$ & 27 (100\%) \\
\hline \multicolumn{5}{|c|}{ Collectivist Style } \\
\hline Predominant & $18(38.3 \%)$ & $13(29.5 \%)$ & $6(17.6 \%)$ & $12(42.9 \%)$ \\
\hline Moderate presence & $26(55.3 \%)$ & $26(59.1 \%)$ & $25(73.5 \%)$ & $12(42.9 \%)$ \\
\hline Unremarkable & $3(6.4 \%)$ & $5(11.4 \%)$ & $3(8.8 \%)$ & $4(14.3 \%)$ \\
\hline Total & $47(100 \%)$ & $44(100 \%)$ & $34(100 \%)$ & $28(100 \%)$ \\
\hline \multicolumn{5}{|c|}{ Directive Style } \\
\hline Predominant & $13(28.3 \%)$ & $17(37 \%)$ & $9(25.7 \%)$ & $9(34.6 \%)$ \\
\hline Moderate presence & $26(56.5 \%)$ & $17(37 \%)$ & $19(54.3 \%)$ & $15(57.7 \%)$ \\
\hline Unremarkable & $7(15.2 \%)$ & $12(26.1 \%)$ & $7(20 \%)$ & $2(7.7 \%)$ \\
\hline Total & $46(100 \%)$ & $46(100 \%)$ & 35 (100\%) & $26(100 \%)$ \\
\hline
\end{tabular}

Source: Research data, 2017-2018.

No statistically significant differences were found, i.e., those with a value of $p<0.05$ in the multiple comparisons made between the management styles and the units that make up the surgical ward. The same occurred with comparisons between management styles and sociodemographic data such as smoking, physical activity, sleep and latest medical examination.

A comparison of the individualist management style and the work shifts showed a significant difference between this management style and non-traditional work shift and work performed in the weekends (these two shifts were analyzed concomitantly and named as others), with $P=0.025$. On the other hand, absence from work had a significant correlation with three management styles, as follows: individualist $P=$ 0.001 , collectivist $P=0.0034$ and directive $P=0.003$.

\section{DISCUSSION}

Based on sociodemographic information, it can be seen that the workers of the surgical units investigated in this study are predominantly women aged 45 years or older. It is noteworthy that the length of time working in the professional activity in the institution ranged mostly between 10 and 20 years and more than 20 years, indicating that there is a low percentage of turnover among the workers, which is a positive aspect. Studies ${ }^{(15-16)}$ show that high turnover rates in the nursing field can have a negative impact on the quality and safety of care. Turnover also impairs the productivity and motivation of health professionals ${ }^{(17)}$.

Regarding lifestyle, almost the entire sample reported not smoking and more than half of the participants reported 
sleeping well, indicating that the workers are concerned about their health. On the other hand, more than half of the sample does not do regular physical activity, which can cause health problems for these workers, including problems in the development of professional activities ${ }^{(18)}$.

As for the results of the EEG, the "Individualist" factor was rated by workers as unremarkable in the units investigated. However, the individualist style showed significance with non-traditional and weekend shifts. In the institution where the study was conducted, the professionals who work in non-traditional work shifts perform their activities with different teams, in which there is not a single reference team, as their work shift does not have defined start and end times like the others (e.g. mid-afternoon until early evening). The professionals that perform their duties in the weekend also work with more than one team, with longer intervals during the week. There was a significant correlation between work in non-traditional shifts and work shift because these working conditions do not favor the existence of a single leader or a single team. One study found a relationship between the work schedule adopted and the prevalence of mental load, with more evidence for work in shifts. According to the referred study, work in shifts increase the risk for mental burden and the accumulation of functions increase the risk for mental and psychological burden ${ }^{(19)}$.

Moreover, individualist, collectivist and directive management styles showed a positive correlation with absence from work. The cause of absenteeism or of sickness absence due to illness by the nursing team is related to work organization and the strategies used to reduce absenteeism, when operated incorrectly, can often overburden the teams even more, feeding back the absenteeism itself(20), which reinforces the importance of the type of management adopted. The normative style was the only one that did not show a positive correlation with absence from work, which can be attributed to the fact that this is a characteristic of nursing work.

When the organization of work provides autonomy, the use of technical and creative skills, horizontal and vertical relationships based on trust, cooperation and the definition of rules by the work group, are factors that transform or minimize suffering, favoring the feeling of pleasure at work, because the tasks performed are perceived as more significant for the workers. This occurs when tasks have a beginning, middle and end, with visualization of work results, flexibility of decisions and work processes and activities that require initiative and decision making are developed ${ }^{(12)}$.

On the other hand, it should be noted that the presence of rules does not mean that workers cannot exercise their autonomy and are controlled. One study found that a management that exercises excessive control and monitoring of the staff can hinder any attempt to achieve better safety in the workplace ${ }^{(21)}$.

A study conducted at the Mobile Emergency Care Service (SAMU) found a predominance of managerial and collectivist management styles ${ }^{(22)}$. Tight control of work through norms and rules guides decision-making processes and establishes the operating procedures. However, absolute control over the organization of work is impossible, and the exchange of experiences between team members encourages them to reflect on the meaning of their experience, creating a sense of accomplishment.

This feeling produced by the exchange of experiences among the team members is consistent with the "collectivist" factor of the Scale of Management Styles. In this factor, the means showed great variation. However, half of its items were characterized as predominant and $46.2 \%$ (72) of the workers considered this management style to be predominant. In the study carried out at the SAMU of Distrito Federal (DF), the collectivist management style was also among the most prevalent styles ${ }^{(22)}$. In the collectivist style, the organization is a group seen as perfect, which has pride, confidence and organizational self-esteem, and in which the actions of the members are intended to meet organizational interests even if these individuals are not properly valued ${ }^{(8)}$.

Another study points out that integration among professionals was the style most used by the nursing team in dealing with and managing conflicts, followed by accommodation. On the other hand, avoidance and competition were the least used styles. The authors concluded that updated evidence is useful for the elaboration of interventions aimed to provide nurses with positive management styles that are necessary to reduce and manage conflicts. Such interventions may include structured training in conflict management, team building and conflict training activities, continuous professional development, reflection, simulation and role -play exercises ${ }^{(23)}$.

Corroborating this idea, undergraduate students in northern Italy used training tools, through games, to develop conflict management skills. This allowed for the development of competences about facing the challenges of conflict management inherent to the profession, through learning strategies, favoring the overcoming of the individualist stereotype in the representation of conflicts and highlighting the interdependence of social interaction ${ }^{(24)}$.

These innovations are consistent with the "Directive" factor, in which the means ranged between 2.84 and 3.52, and five items were classified as moderate presence and one as predominant, and item 23 , innovation is valued in this organization, obtained the highest mean in this factor. This style is centered on productivity with competitiveness and 
professional fulfillment, being focused on entrepreneurship and characterized by the constant activity of the members of the organization, who are always looking for new challenges, want praise, seek a promotion and want recognition and prestige ${ }^{(8)}$. In a study consistent with this line of thought, nurses stated that creativity leads to innovation and entrepreneurship. They mentioned improvement in the quality of patient care, in the quality of work, in the lives and social interactions of health professionals, promotion of organization, but also unfavorable results. The study concluded that nurses' creativity in healthcare organizations can lead to major changes in nursing practice, improving care and organizational performance. Therefore, policy makers, nurse educators, nursing and hospital managers must provide a stimulating environment that is conducive to creative thinking, giving nurses the opportunity for flexibility, creativity, support for change and risk taking ${ }^{(25)}$.

In this regard, the training of nurses plays an important role in building an entrepreneurial profile of the students. In a study carried out in the state of Paraná, the authors concluded that nursing residents are determined to be successful, but some directive trends are deficient, which can hinder the completion of this entrepreneurial profile. Older residents with greater professional experience showed more enthusiasm and determination, although the fact that the participants had not yet completed training may have contributed to entrepreneurial trends "negatively" assessed ${ }^{(26)}$.

Another study showed that the management styles adopted by the leaders can also influence workplace safety and emphasized that leaders who seek to improve workplace safety must continuously focus on safety, both in their communication and in acting as role models. The study also points out that a management that exercises excessive control of the staff can undermine attempts to achieve better safety in the workplace. It also stresses that safety leadership training programs should focus on safety issues, regardless of the overall leadership style. It was also concluded that the distinction between injuries of varying severity (that is, including measures of minor injuries) could facilitate the detection of relationships between organizational factors and injury outcomes ${ }^{(21)}$.

Corroborating the importance of nursing management in the health of workers who perform their activities in the surgical ward, a study points out the fundamental role of this management in the structuring of surgical teams, taking into account the relationships between the professionals, which clearly generates motivation and satisfaction. Nursing management had a low impact on the quality of life and work of nurses, nursing technicians and nursing assistants in the area. On the other hand, the authors reported that the psychological domain had a considerable impact on the quality of life of the staff, suggesting that there should be greater concern with the workers' health, and that the service should offer psychological support, improve conflict management and reduce stressors, in addition to providing ergonomic equipment to the professionals, since the physical domain has also been impaired. Another aspect reported was income, as low paid health professionals tend to face long working hours under stressful conditions, which impact their quality of life. Academic training also had a major impact on these workers, and there is still a need to value nursing professionals more and improve the work infrastructure, indicating that the quality of life of nursing professionals in the surgical ward remains a challenge ${ }^{(27)}$.

\section{QCONCLUSION}

The study concluded that the surgical ward units, post-anesthesia care unit, ambulatory surgery center and material and sterilization center have different modes of management in their work environment.

Among the styles of the EEG scale that are present in the units, there is a predominance of the collectivist management mode, followed by the normative and directive styles in which there was a moderate presence. The individualist management style was assessed as unremarkable by more than half of the sample.

The presence of a collectivist management is consistent with the characteristics of nursing work, which is focused on patient care, planned and performed jointly and in line with the multidisciplinary health team, in the pursuit of comprehensive care.

The individualist style was unremarkable in the four units of the surgical ward. The only unit that had a predominant management mode was the post-anesthesia recovery room, where normative management predominated, followed by collectivist management, which was also assessed as predominant and moderately present.

In the surgical ward and in the materials and sterilization center there was a balance between the normative, collectivist and directive management styles, with a moderate presence.

Finally, the ambulatory surgery center, in which the directive style was also assessed between moderate and predominant, while the normative and collective styles were moderately present. These results corroborate the particularities of the sector where characteristics of three other units are present in one unit, requiring professionals to implement a creative dynamics. 
The results obtained here provide valuable data that can be used in further research and investigation both in the study area and in other scenarios. It is proposed therefore that this study, whose limitation is the fact that it was carried out in a specific institutional area, be expanded.

The objectives of the study were achieved, and since the modes of management interfere with the dynamics of the staff, the organization of work and can pose psychosocial risks to the workers in the surgical ward, the topic addressed is of great importance. The results contribute to the mapping of these risks, as well as to occupational health actions, quality of life in the workplace, restructuring of organizational processes related to management styles and the importance of management in academic training.

\section{REFERENCES}

1. Giurgiu DI, Jeoffrion C, Roland-Lévy C, Grasset B, Dessomme BK, Moret L, et al. Wellbeing and occupational risk perception among health care workers: a multicenter study in Morocco and France. J Occup Med Toxicol. 2016;11:20. doi: https://doi.org/10.1186/s12995-016-0110-0

2. Baruki LV. Riscos psicossociais e saúde mental do trabalhador: por um regime jurídico preventivo. 2a ed. São Paulo (SP): LTr; 2018.

3. AndradeVF, Bizzo WA. Comparative analysis of social responsibility management standards and their comprehensiveness. Gest Prod. 2018;25(4):807-25. doi: https://doi.org/10.1590/0104-530×3866-18

4. Vasconcelos RO, Bohrer CD, Rigo DFH, Marques LGS, Oliveira JLC, Tonini NS, et al. Meios para a gerência de enfermagem utilizados em unidades hospitalares críticas. Enferm Foco. 2016;7(3/4):56-60. doi: https://doi.org/10.21675/2357707X.2016.V7.n3/4.944

5. Teles J. Particularidades da gestão de enfermagem em instituições psiquiátricas [editorial]. Rev Portug Enferm Saúde Mental. 2017;(5):6-7. doi: https://doi. org/10.19131/rpesm.0159

6. Martins FZ, Dall'Agnol CM. Surgical center: challenges and strategies for nurses in managerial activities. Rev Gaúcha Enferm. 2016;37(4):e56945. doi: https:// doi.org/10.1590/1983-1447.2016.04.56945

7. Silva VLS, Camelo SHH, Soares MI, Resck ZMR, Chaves LDP, Santos FC, et al. Leadership practices in hospital nursing: a self of manager nurses. Rev EsC Enferm USP. 2017:51:e03206. doi: https://doi.org/10.1590/ s1980-220x2016099503206

8. Facas EP. Protocolo de avaliação dos riscos psicossociais no trabalho contribuições da psicodinâmica do trabalho [tese]. Brasilia (DF): Universidade de Brasília; 2013 [cited 2019 Nov 3]. Available from: https://core.ac.uk/ download/pdf/33547867.pdf

9. Soder R, Oliveira IC, Silva LAA, Santos JLG, Peiter CC, Erdmann AL. Desafios da gestão do cuidado na atenção básica: perspectiva da equipe de enfermagem. Enferm Foco. 2018;9(3):76-80. doi: https://doi.org/10.21675/2357707X.2018.v9.n3.1496
10. Sociedade Brasileira de Enfermagem em Centro Cirúrgico. Diretrizes de práticas em enfermagem cirúrgica e processamento de produtos para a saúde. 7. ed. São Paulo: SOBECC; 2017.

11. Hospital de Clínicas de Porto Alegre (BR) [Internet]. Porto Alegre: HCPA; c2020 [cited 2020 Jan 10]. Enfermagem em centro cirúrgico: serviços de enfermagem; [about 4 screens]. Available from: https://www.hcpa.edu.br/ assistencia-servicos-de-enfermagem-enfermagem-em-centro-cirurgico

12. Facas EP, Mendes AMB. Estrutura fatorial do protocolo de avaliação dos riscos psicossociais no trabalho [Internet]. Brasilia: Núcleo Trabalho, Psicanálise e Crítica Social, Instituto de Psicologia, UnB; 2018 [cited 2019 Apr 10]. Available from: http://nucleotrabalho.com.br/wp-content/uploads/2018/12/FacasMendes-Estrutura-Fatorial-do-Protocolo-de-Avalia\%C3\%A7\%C3\%A30-dosRiscos-Psicossociais-no-Trabalho1.pdf

13. Torman VBL, Coster R, Riboldi J. Normalidade de variáveis: métodos de verificação e comparação de alguns testes não-paramétricos por simulação. Rev HCPA. 2012 [cited 2020 Jan 10];32(2):227-34. Available from: https://seer. ufrgs.br/hcpa/article/view/29874/19186

14. Ministério da Saúde (BR), Conselho Nacional de Saúde. Resolução nº 466, de 12 de dezembro de 2012. Diretrizes e normas regulamentadoras de pesquisas envolvendo seres humanos. Diário Oficial da União. 2013 jun 13;150(112 Seção 1):59-62.

15. Martins MS, Matos E, Salum NC. Turnover of nursing workers in an adult emergency unit. Texto Contexto Enferm. 2019;28:e20160069. doi: https://doi. org/10.1590/1980-265x-tce-2016-0069

16. Balabanian YCC, Monteiro MI. Factors related to voluntary external turnover of nursing professionals. Rev Esc Enferm USP. 2019;53:e03427. doi: https://doi. org/10.1590/S1980-220X2017033403427

17. Carvalho ACM, Silva PC, Nascimento LM. Causas e consequências da rotatividade de pessoas: estudo de caso em uma multinacional de fast food. Pensar Acad. 2019;17(2):138-60. doi: https://doi.org/10.21576/rpa.2019v17i2.607

18. Halloway S, Buchholz SW. Sedentary behavior: considerations for the nurse practitioner. J Nurse Pract. 2017;13(1):59-63. doi: https://doi.org/10.1016/j. nurpra.2016.08.024

19. Ferreira MM, Ferreira C. Carga mental e carga psíquica em profissionais de enfermagem. Rev Portug Enferm Saúde Mental. 2014 [cited 2020 Dec 4]:4752. Available from: http://www.scielo.mec.pt/pdf/rpesm/nspe1/nspe1a08.pdf

20. Silva Junior FF, Merino EAD. Proposal for management of absenteeism among hospital nurses: a systematic review. Acta Paul Enferm. 2017;30(5):546-53. doi: https://doi.org/10.1590/1982-0194201700079

21. Molnar, MM, Schwarz UVT, Hellgren J, Hasson H, Tafvelin S. Leading for safety: A question of leadership focus. Saf Health Work. 2019;10(2):180-7. doi: https:// doi.org/10.1016/j.shaw.2018.12.001

22. Araújo LKR. Protocolo de avaliação dos riscos psicossociais: adequação ao SAMU-DF [dissertação]. Rio de Janeiro (RJ): Fiocruz/ENSP; 2017 [cited 2020 Jan 5]. Available from: https://www.arca.fiocruz.br/bitstream/icict/24062/2/ ve_Luciane_Kozicz_ENSP_2017.pdf

23. Labrague LJ, Al Hamdan Z, McEnroe-Petitte DM. An integrative review on conflict management styles among nursing professionals: implications for nursing management. J Nurs Manag. 2018;26(8):902-17. doi: https://doi. org/10.1111/jonm. 12626 
24. Bruno A, Dell'aversana G, Guidetti, G. Developing organizational competences for conflict management: the use of the prisoner's dilemma in higher education. Front Psychol. 2018;9:376 doi: https://doi.org/10.3389/fpsyg.2018.00376

25. IsfahaniSS, Hosseini MA, Khoshknab MF, PeyroviH, KhankeHR. Nurses'creativity: advantage or disadvantage. Iran Red Crescent Med J. 2015;17(2):e59665. doi: https://doi.org/10.5812/ircmj.20895
26. Ferreira AMD, Rossaneis MA, Oliveira JLC, Haddad MCFL, Vannuchi MTO. The entrepreneur profile of nursing residentes. Rev Baiana Enferm. 2018;32:e27365. doi: https://doi.org/10.18471/rbe.v32.27365

27. Carvalho AMB, Cardoso JA, Silva FAA, Lira JAC, Carvalho SM. Qualidade de vida no trabalho da equipe de enfermagem do centro cirúrgico. Enferm Foco. 2018;9(3):35-41. doi: https://doi.org/10.21675/2357-707X.2018.v9.n3.1159

\section{- Corresponding author:}

Cecília Helena Glanzner

E-mail: glanznercecilia@gmail.com

\section{Associate editor:}

Graziella Badin Aliti

Editor-in-chief:

Approved: 05.05.2020
Maria da Graça Oliveira Crossetti 